\title{
1. Debunking revisionist understandings of environmental cooperative federalism: collective action responses to air pollution
}

\section{Robert L. Glicksman and Jessica A. Wentz}

From its inception in 1970, modern environmental law has been a joint venture between the federal government and the states. When Congress enacted the Clean Air Act (CAA) of $1970^{1}$ it crafted the model for much of the pollution control legislation enacted in the ensuing decade. Commonly referred to as cooperative federalism, the model entailed delegating authority to a federal agency, the Environmental Protection Agency (EPA), to enact standards and take other action to achieve clean air protection and enhancement goals ${ }^{2}$ and inviting states to participate in implementation, permitting, and enforcement. ${ }^{3}$ With some variations, Congress built subsequent statutory efforts to protect water quality and prevent land pollution along similar lines, 'shar[ing] governmental responsibilities for regulating private activity' with the potential to create environmental harm between the federal government and the states. ${ }^{4}$ In the environmental context, cooperative federalism involves federal

1 Pub. L. No. 91-604, 84 Stat. 1676 (1970) (codified as amended at 42 USC $\S \S 7401-7671 q)$.

242 USC $\$ 7401(\mathrm{~b})(1)$ (declaring purpose to 'protect and enhance the quality of the Nation's air resources').

3 For a description of the basic cooperative federalism model reflected in the federal pollution control statutes, see Glicksman, Robert L., 'From Cooperative to Inoperative Federalism: The Perverse Mutation of Environmental Law and Policy' (2006) 41 Wake Forest L. Rev. 719, 719-21, 737-43.

4 Coggins, George Cameron and Robert L. Glicksman, Public Natural Resources Law, vol. 1, 2nd edn (Thomson/West, Eagan, Minn. 2007) § 5:3. 
inducement, but not coercion of state participation in a coordinated federal program. ${ }^{5}$

Despite decades of experience with the CAA's version of cooperative federalism, fundamental disagreements persist not only about the merits of that model, but also about what Congress intended when it delineated EPA and state roles in the 1970 Act and subsequent amendments. One view is that the pollution laws that Congress adopted in the 1970s, beginning with the CAA, fundamentally changed the structure of environmental law by carving out 'a significant role [for states] to play under this "cooperative" approach to federalism,' while 'clearly [making] EPA the senior partner in the relationship. The states had lost their predominant position.' ${ }^{6}$ The Court of Appeals for the Tenth Circuit expressed a similar understanding, summarizing the CAA model as one in which states are responsible for adopting plans to implement EPA's national ambient air quality standards (NAAQS), but 'with federal oversight.'7

Some judicial decisions provide a significantly different depiction of the roles of federal and state regulators under the CAA. The most prominent such decision is Justice Kennedy's dissenting opinion in Alaska Department of Environmental Conservation $v E P A,{ }^{8}$ in which the Supreme Court held that the CAA authorizes substantive review by EPA of state permitting decisions for stationary sources in prevention of significant deterioration (PSD) areas. Justice Kennedy responded to EPA's contention that such review helps prevent a 'race to the bottom' in which states lower environmental standards to attract industry by finding 'EPA's distrust of state agencies' to be 'inconsistent with the Act's clear mandate that States bear the primary role in controlling pollution.' According to Kennedy, 'Congress made the overriding judgment that States are more responsive to local conditions and can strike the right balance between preserving environmental quality and advancing competing objectives.' 10 He protested EPA's lack of trust in the states and charged that vesting in EPA veto power over state PSD permits violated

5 Fischman, Robert, 'Cooperative Federalism and Natural Resources Law' (2006) 14 NYU Envtl LJ 179, 184.

6 Andreen, William L., 'Of Fables and Federalism: A Re-Examination of the Historical Rationale for Federal Environmental Regulation' (2012) 42 Envtl L. 627, 629.

7 Oklahoma v EPA 723 F.3d 1201, 1204 (10th Cir. 2013).

8540 US 461 (2004).

9 Ibid. at 506-07.

10 Ibid. at 507. 
'the established presumption that States act in good faith.' ${ }^{11}$ Justice Kennedy was also dismayed by the 'broader implications' of the Court's decision:

The CAA is not the only statute that relies on a close and equal partnership between federal and state authorities to accomplish congressional objectives. Under the majority's reasoning, these other statutes, too, could be said to confer on federal agencies ultimate decision-making authority, relegating States to the role of mere provinces or political corporations, instead of coequal sovereigns entitled to the same dignity and respect. If cooperative federalism is to achieve Congress' goal of allowing state governments to be accountable to the democratic process in implementing environmental policies, federal agencies cannot consign States to the ministerial tasks of information gathering and making initial recommendations, while reserving to themselves the authority to make final judgments under the guise of surveillance and oversight. ${ }^{12}$

Echoing Justice Kennedy's dissent, the Court of Appeals for the Fifth Circuit recently interpreted the CAA as 'confin[ing] the EPA to the ministerial function of reviewing [state implementation plans] for consistency with the Act's requirements,' reasoning that this narrow reading of EPA's authority 'reflects the balance of state and federal rights and responsibilities characteristic of our federal system of government.' 13 Similarly, a minority report issued by the Senate Committee on Environmental and Public Works in 2013 expressed concern that 'EPA, instead of cooperating with the States as equal and valued partners, is coopting and coercing the States by treating them as mere regional offices of a massive federal environmental bureaucracy.' ${ }^{14}$

Thus, despite decades of experience with the CAA, courts and commentators offer dramatically different descriptions of its cooperative

11 Ibid. He also asserted that even EPA agreed that 'States, by and large, take their statutory responsibility seriously,' and that EPA itself had admitted that its 'fears about a race to the bottom bear little relation to the real-world experience under the statute.' Ibid.

12 Ibid. at 518 (emphasis added) (citations omitted).

13 Luminant Generation Co., LLC v EPA, 675 F.3d 917, 921 (5th Cir. 2012). See also Luminant Generation Co., LLC v EPA, 714 F.3d 841, 846 (5th Cir. 2013).

14 US Senate, Comm. on Environment and Public Works, Minority Report, Cooperative Federalism, Neglecting a Cornerstone Principle of the Clean Air Act: President Obama's EPA Leaves States Behind 13 (31 October 2013) (hereinafter Cooperative Federalism). The report also postulated that 'mere inadequacy of a [state implementation plan] in the eyes of EPA is not a sufficient basis for disapproving' the plan. Ibid. at 17. 
federalism enterprise. Either the statute makes EPA the dominant partner, and the opportunity afforded to the states to participate in fashioning air pollution control policy, albeit significant, "is the power of the servant, not the sovereign, ${ }^{15}$ or Congress intended to make EPA and the states equal partners. ${ }^{16}$

This chapter demonstrates that the vision of CAA cooperative federalism as an equal partnership bears no resemblance to the allocation of power Congress established in adopting the CAA. Congress made EPA the dominant partner because experience convinced it that the states lacked the will or the capacity to achieve its air quality protection goals. While it recognized that states' familiarity with local conditions made a significant state role in deciding how to implement some federal standards desirable, it also acted on the premise that a series of collective action problems could be effectively addressed only by vesting predominant policymaking authority in a federal agency. Experience in implementing the 1970 CAA reinforced these sentiments, inducing Congress to tilt the balance of power even more heavily toward EPA in the 1977 and 1990 amendments. Congress allowed the states to avoid federal supervision or constraints only when they adopt emission controls more stringent than the floors established by EPA (except in limited areas such as emission controls for new motor vehicles). This approach does not disrespect state sovereignty. As the Supreme Court recognized in a 1981 decision upholding a statute regulating surface mining, this cooperative federalism approach is less intrusive than the complete preemption of state authority to regulate activities creating environmental harms with interstate effects to which Congress could have resorted. ${ }^{17}$

This chapter emphasizes the predominant role of EPA vis-à-vis the states in various CAA programs. It refutes recent characterizations of its cooperative federalism design as intended to create an 'equal partnership' between EPA and the states. Instead, the legislative history reveals that Congress crafted key statutory programs to address collective action problems that it regarded the states as incapable of solving. Finally, the chapter briefly examines the desirability of this cooperative federalism model both in controlling conventional air pollution and in seeking to

15 Gerken, Heather K., 'The Federalis(m) Society' (2013) 36 Harv JL \& Pub Pol'y 1, 3.

16 In limited contexts under other pollution control statutes, Congress has given the states the power to override federal actions. See Carlson, Ann E., 'Reverse Preemption' (2013) 40 Ecology LQ 583.

17 Hodel v Va. Surface Mining \& Reclamation Ass'n, Inc., 452 US 264, 289-91 (1981). 
address greenhouse gases (GHGs) that contribute to climate disruption. The authors find that the CAA's delegation to EPA of the dominant role in controlling conventional air pollution, subject to state power to exceed federal minimums, has largely succeeded in addressing conventional air pollution problems. Moreover, this version of cooperative federalism promises to be an effective approach for regulating GHG emissions. Unfortunately, judicial decisions circumscribing EPA's authority under the CAA have undermined federal efforts to address lingering collective action problems such as interstate air pollution. An accurate application of the cooperative federalism model actually established under the CAA is imperative for the successful implementation and enforcement of the statute's programs and goals.

\section{THE CAA MAKES EPA THE DOMINANT COOPERATIVE FEDERALISM PARTNER}

That Congress sought to protect and enhance air quality through a cooperative federalism venture is not in dispute. The CAA finds that 'Federal financial assistance and leadership is essential for the development of cooperative Federal, State, regional, and local programs to prevent and control air pollution.' ${ }^{18}$ Congress committed the federal government to providing technical and financial assistance to state and local governments to help them develop and implement air pollution control programs. ${ }^{19}$ EPA must encourage cooperative activities by state and local governments and improved laws to control air pollution, in pursuit of uniformity to the extent it is practicable 'in the light of varying conditions and needs.' ${ }^{20}$ EPA may make grants to support regional, state, and local programs. ${ }^{21}$ None of these provisions, however, establishes the states as equal partners with EPA.

The Act declares air pollution control at its source to be 'the primary responsibility of States and local governments.' 22 Moreover, as indicated below, it authorizes EPA to step in if the states do not fulfill that responsibility. Notably, the statute refers to state responsibilities, not rights. Responsibilities imply duties, whose breach carries consequences. The reference to responsibilities contrasts with the Clean Water Act's

\footnotetext{
42 USC $\S 7401(a)(4)$.

Ibid. at $\$ 7401(b)(3)$.

Ibid. at $\S 7402(a)$.

Ibid. at $\S 7405$.

$22 I d$. at $\$ 7401(\mathrm{a})(3)$.
} 
enunciation of a federal policy of recognizing, preserving, and protecting 'the primary responsibilities and rights of States to prevent, reduce, and eliminate pollution, ${ }^{23}$ and with the same law's renunciation of any intent to supersede, abrogate, or impair state authority to allocate quantities of water within a state's jurisdiction. ${ }^{24}$ When the CAA refers to states' 'rights,' it preserves their right, with exceptions for mobile source controls, to enact standards more stringent than applicable federal rules. ${ }^{25}$ States are therefore free to craft air pollution control policy without EPA supervision only when they choose to exceed federal minimum standards.

The CAA's allocation of authority between EPA and the states is usually clear-cut. EPA is responsible for adopting the NAAQS that form the Act's central pollution control mechanism, although it may seek technical input from state and local governments, among others. ${ }^{26}$ Each state has 'the primary responsibility for assuring air quality' within its borders by adopting a state implementation plan (SIP) for each NAAQS. ${ }^{27}$ States must submit each SIP to EPA to determine whether it meets mandatory requirements. ${ }^{28}$ EPA must approve an SIP that meets these requirements; ${ }^{29}$ the Supreme Court in an early CAA case concluded that EPA has

no authority to question the wisdom of a State's choices of emissions limitations if they are part of a plan which satisfies [the Act's minimum requirements]. Thus, so long as the ultimate effects of a State's choices of emissions limitations is compliance with the [NAAQS], the state is at liberty to adopt whatever mix of emission limitations it deems best suited to its particular situation. ${ }^{30}$

33 USC $\S 1251$ (b) (emphasis added).

24 Ibid. at $\$ 1251(\mathrm{~g})$.

2542 USC $\$ 7416$.

26 Ibid. at $\$ 7408(\mathrm{a})-(\mathrm{b})$.

27 Ibid. at $\$ 7407(\mathrm{a})$.

28 Ibid. at $\$ 7410(a)(1)-(2)$. Each SIP must include, among other things, enforceable emissions limitations and other control measures, schedules and timetables for compliance, monitoring requirements, enforcement provisions, and measures to prevent interstate pollution. Ibid. at $\S 7410$ (a)(2).

29 Ibid. at $\$ 7410(\mathrm{k})(3)$.

30 Train v Natural Res. Def. Council, Inc., 421 US 60, 79 (1975). See also ibid. at 86-87 (stating that Congress 'left to the state considerable latitude in determining specifically how the [NAAQS] would be met. This discretion includes the continuing authority to revise choices about the mix of emissions limitations.'). 
Nevertheless, Congress specified the mandatory components of each state plan, delegated to EPA the power to assess whether a plan meets those requirements, and authorized EPA to adopt a federal implementation plan if a state fails to abide by its responsibilities. ${ }^{31}$ Likewise, the statute gives the states the first opportunity to enforce SIP provisions or permits, but allows EPA to enforce if the states do not. ${ }^{32}$

Other CAA programs provide less authority to the states, or none at all. Whereas the states are responsible in the first instance for developing and imposing controls on sources that emit pollutants covered by the NAAQS, Congress gave EPA the power to issue technology-based emission standards for new stationary sources ${ }^{33}$ and newly manufactured mobile sources, ${ }^{34}$ and to issue technology-based and, if necessary, health-based standards for hazardous air pollutants. ${ }^{35}$ States may adopt and submit for EPA approval a program to implement and enforce emission standards for hazardous air pollutants to displace the federal program, but state standards may not be less stringent than EPA's standards. ${ }^{36}$ EPA is responsible for enforcing all of these federal emission standards. ${ }^{37}$

States may adopt controls more stringent than EPA's standards for new sources or sources of hazardous air pollutants, but the statute completely preempts state power to adopt tailpipe emission standards for new motor vehicles. $^{38}$ EPA may waive this prohibition by allowing California to adopt more stringent standards, ${ }^{39}$ and, if it does so, any other state may adopt California's standards in lieu of EPA's. ${ }^{40}$

3142 USC $\$ 7410$ (c).

32 Ibid. at $\$ 7413(\mathrm{a})$.

33 Ibid. at $\$ 7411$. EPA may require states to submit plans establishing standards of performance for existing sources in industrial categories covered by the new source standards of performance issued under $\S 111$. EPA retains backup regulatory authority, with the discretion to issue a plan for a state failing to submit a satisfactory one. Ibid. at $\$ 7411(d)$.

34 Ibid. at $\$ \S 7521,7547,7571$.

35 Ibid. at $\$ 7412$.

36 Ibid. at $\$ 7412(l)$.

37 Ibid. at $\$ \S 7413(a)(3),(b)-(c), 7523-24$.

38 Ibid. at $\$ 7543$ (a).

39 Ibid. at $\$ 7543(\mathrm{~b})$.

40 Ibid. at $\$ 7507$. Congress included this waiver procedure in the 1970 CAA because it recognized that California regulators might need to impose more stringent tailpipe emissions standards to address the state's uniquely severe pollution problems and to enable California to meet the NAAQS. See 116 Cong. Rec. 19,231-37 (1970). Air quality in Los Angeles, for example, was five times 
EPA is also largely responsible for implementing the programs added in the 1990 amendments to control acid deposition ${ }^{41}$ and emissions of substances that deplete the stratospheric ozone layer. ${ }^{42}$ The 1990 amendments also authorized states to seek EPA approval of permit programs that encompass all aspects of the CAA's emission controls for stationary sources, but the statute prescribes the mandatory minimum contents of state programs and authorizes EPA to determine whether a state program is adequate. State-issued permits must incorporate all controls applicable to the source covered by the permit, including those issued solely by EPA. ${ }^{43}$ EPA may reject a state's proposed permit and if the state does not make changes identified by EPA, EPA may deny or issue the permit itself. ${ }^{44}$ EPA also may revoke a state permit program if it determines that the state is not adequately administering and enforcing the program. ${ }^{45}$ Thus, with the exception of state power to adopt controls more stringent than federal standards for stationary sources, EPA either unilaterally adopts pollution control standards or determines whether state provisions meet state responsibilities. It is difficult to conceptualize the states as equal partners with EPA under virtually any aspect of the statutory program (other than the power to adopt controls more stringent than EPA's), no less under the statute as a whole.

\section{COLLECTIVE ACTION RATIONALES FOR FEDERAL ENVIRONMENTAL REGULATION}

A significant federal role in environmental lawmaking requires justification, given the traditional state role in protecting health and safety through exercise of the police power, and the preference for policymaking by state and local officials in light of their superior political accountability and familiarity with local conditions. Collective action theory justifies environmental laws such as the CAA that carve out a predominant role for the federal government. That theory examines the

worse than in any other city in the country. Ibid. at 19,237 (remarks of Rep. Springer).

\footnotetext{
$41 \quad 42$ USC $\$ \$ 7651-51 o$.

42 Ibid. at $\$ \$ 7671-7671 q$.

43 Ibid. at $\$ \S 7661 \mathrm{a}, 7661 \mathrm{c}(\mathrm{a})$.

44 Ibid. at $\$ 7661 d(b)-(c)$.

45 Ibid. at $\$ 7661 \mathrm{a}(\mathrm{i})$.
} 
dynamics of individual behavior in cooperative group settings. ${ }^{46}$ Much of environmental regulation generally can be explained as an effort to avert the tragedy of the commons, which is a collective action problem that causes shared resources to be overused. ${ }^{47}$ Five more specific collective action problems justify significant federal authority to adopt and implement environmental law instead of leaving such matters within state control: transboundary externalities, the benefits of resource pooling, avoidance of a race to the bottom, the need for uniformity, and avoidance of the 'not in my backyard' syndrome. ${ }^{48}$ With the exception of the last one, Congress relied on all of these collective action problems in authorizing EPA to adopt and implement air pollution controls itself or to supervise state implementation and displace the authority of underperforming states.

\section{Transboundary Externalities}

One of the clearest justifications for federal intervention is the fact that air pollution can create negative externalities in states downwind from the pollution source. ${ }^{49}$ The core concern is that a state enjoying the economic benefits of the activity producing interstate air pollution without having to address adverse environmental impacts will abstain from regulation. Federal intervention is justified because the source state has no incentive to regulate in-state sources that pollute downwind states and downwind states have no authority to regulate those sources.

\section{Resource Pooling}

The federal government can pool resources from across the country to develop and implement regulatory programs, giving it more resources than any individual state has to collect technical information, conduct scientific studies, and develop and enforce standards. In some instances,

46 Glicksman, Robert L. and Richard E. Levy, 'A Collective Action Perspective on Ceiling Preemption by Federal Environmental Regulation: The Case of Global Climate Change' (2008) 102 Nw U.L. Rev. 579, 579 n.1. See generally Olson, Mancur, The Logic of Collective Action: Public Goods and the Theory of Group (Cambridge, Mass.: Harvard University Press 1965).

47 Glicksman and Levy, supra n.46, p. 593.

48 See ibid., pp. 593-602.

49 See Merrill, Thomas W., 'Golden Rules for Transboundary Pollution' (1997) 46 Duke L.J. 931; Revesz, Richard L., 'Federalism and Interstate Environmental Externalities' (1996) 144 U. Pa. L. Rev. 2341. 
the federal government can carry out these activities more efficiently than could multiple states acting independently.

\section{Race to the Bottom}

Concerns about a 'race to the bottom' among states may justify federal regulation. If states have different environmental standards, regulated industries may migrate from jurisdictions with more stringent standards to those with less stringent standards. This dynamic creates a perverse incentive for each state to relax its environmental standards to gain the economic benefits and tax revenues that polluting businesses provide. Interstate competition for industry can lead all states to settle on a lowest common denominator of environmental degradation. States imposing stringent standards are penalized. ${ }^{50}$ Federal regulation can halt the race by establishing a floor below which the states may not go.

\section{Uniform Standards}

Exclusive federal regulation provides uniform standards. The key advantage of uniform regulation is that it reduces production and transaction costs for regulated entities supplying goods and services in interstate commerce, such as manufacturers of new vehicles. ${ }^{51}$ Uniform standards avoid the need for industries whose products have a national market to comply with multiple, divergent state standards. Although states are free to harmonize their standards, it is typically easier to achieve uniformity through the imposition of exclusive federal standards.

\section{The 'Not In My Backyard’ (NIMBY) Syndrome}

Local opposition to the siting of undesirable (but sometimes necessary) land uses can prompt strict state or local laws that seek to drive those activities elsewhere. If all jurisdictions adopt such laws, socially important activities that necessarily generate adverse environmental effects may

50 See Engel, Kirsten, 'State Environmental Standard-Setting: Is There a "Race” and Is It “to the Bottom”?' (1997) 48 Hastings LJ 271; Esty, Daniel C., 'Revitalizing Environmental Federalism' (1996) 95 Mich. L. Rev. 570; Swire, Peter P., 'The Race to Laxity and the Race to Undesirability: Explaining Failures in Competition Among Jurisdictions in Environmental Law' (1996) 14 Yale L. \& Pol'y Rev. 67.

51 See Engel, supra n.50, at 369. 
be permitted nowhere. NIMBYism is the inverse of the negative externality problem in that the host state bears all or most of the associated environmental burdens, while the economic benefits are more broadly distributed among the states. Although this phenomenon may present a compelling rationale for federal regulation in contexts such as waste disposal, ${ }^{52}$ it is not the basis for federal air pollution control.

\section{CONGRESS RELIED ON COLLECTIVE ACTION RATIONALES TO MAKE EPA THE DOMINANT CAA PARTNER}

Until the mid-twentieth century, air pollution control was the domain of state and local governments. Worsening pollution, growing awareness of its public health consequences, and the perceived failure of states and localities to adequately address pollution combined to generate public demand and congressional support for a dramatic shift in the direction of greater federal power. When Congress passed the 1970 CAA, it chose to vest in the newly created EPA the dominant role in pursuing statutory goals. In doing so, it subscribed to the belief that collective action problems made federal dominance essential for effective air pollution control. Amendments adopted in 1977 and 1990 reinforced the states' subsidiary role, either because states had not responded adequately to past responsibilities under the Act or because collective action problems made it unlikely that they would be able to manage newly discovered problems.

\section{The 1970 Act}

When Congress adopted legislation during the 1960s to protect the public health from air pollution, it carved out a relatively limited role for the federal government. Aside from taking the lead in controlling interstate air pollution and regulating new motor vehicle emissions, federal agencies would primarily set goals and provide financial and technical assistance to state regulators. According to Senator Edmund Muskie, a principal author of the 1970 Act, Congress established a strong regulatory role for the states because it wanted 'to preserve the federal system' and 'recognized that the task of implementing and enforcing the clean air

52 See Glicksman and Levy, supra n.46, at 600-01 (discussing the LowLevel Radioactive Waste Policy Act of 1980). 
program was so enormous that it would be helpful to have effective agencies at the state and local level to get the job done more quickly and thoroughly. ${ }^{53}$ By 1970, however, a House committee report characterized progress under the pre-1970 legislation as inadequate and emphasized the urgency of more expeditious control of sources and more effective enforcement. ${ }^{54}$ The states would continue to participate significantly in pollution control efforts primarily for practical reasons; the federal government lacked the resources to implement the statute by itself and the states and localities were best situated to implement land use and transportation control policies thought to be critical to effective pollution control. ${ }^{55}$

Congress passed the 1970 Act with near unanimity, and yet '[f]ew members of Congress ... expressed any sentiments for the abstract values of state autonomy.' Indeed, 'federal legislators viewed state autonomy with suspicion because the states had failed to impose adequate air pollution controls' when they had the opportunity to do so under the pre-1970 legislation. ${ }^{56}$ Sentiments in favor of state autonomy related principally to state authority to adopt more stringent motor vehicle emission standards than EPA's. Some legislators referred to the states' 'right to have higher standards. ${ }^{57}$ Congress eventually decided to allow California alone to adopt more stringent tailpipe emission standards, but permitted other states to adopt California's standards. ${ }^{58}$

Some policymakers were concerned about protecting rights, but they focused on individual rights to a healthy environment and the need to protect states that took their environmental protection responsibilities seriously. A 1970 Senate report justified vesting in EPA authority to adopt NAAQS by asserting that 'the air is a public resource, and ... those who use that resource must protect it from abuse, to assure the protection of the health of every American.' ${ }^{59}$ Similarly, President Nixon supported the NAAQS program because it would 'provide a minimum standard for

53 Muskie, Edmund S., 'Role of the Federal Government in Air Pollution Control' (1968-1969) 10 Ariz. L. Rev. 17, 17.

54 H.R. Rep. No. 91-1146, pp. 1, 5 (1970). See also Alaska Dep't of Envtl. Conservation v EPA, 540 US 461, 469 (2004) (describing the 1970 Act as the outgrowth of 'dissatisfaction with the progress of existing air pollution programs').

55 See e.g. S. Rep. No. 1196, p. 2 (1970).

56 Dwyer, John P., 'The Practice of Federalism under the Clean Air Act' (1995) 54 Md L. Rev. 1183, 1192-93.

57 See e.g. 116 Cong. Rec. 19, 231 (1970) (remarks of Rep. Saylor).

5842 USC $\$ \$ 7507,7543$.

59 S. Rep. No. 91-1996, at 4 (1970). 
air quality for all areas of the nation, while permitting States to set more stringent standards.' 60 Legislators also feared a race to the bottom, notwithstanding Justice Kennedy's contrary protestations. As one House member put it, 'if we do not have [NAAQS], we find what has happened is that States begin to bid against each other to attract polluting industries ... So I say it is not fair to those States who are trying to do something about pollution to allow such lowering of standards to attract polluting industries into other States.' ${ }^{\prime}$ Similarly, Nixon noted that the NAAQS would protect the interests of industries subject to stringent state controls, which "would otherwise be disadvantaged with respect to competitors' subject to less rigorous controls. ${ }^{62}$ Uniform NAAQS would level the playing field.

The 1970 Act vested responsibility to implement the NAAQS in the states, which could craft pollution control strategies suitable to their social and economic needs. But, as one legislator put it, '[i]f a State hangs back and fails to move out, the Federal government will take over and make rules and regulations amounting to a State plan.' 63 Thus, although Congress afforded the states the opportunity to choose their own paths for meeting the NAAQS, it hardly made the states equal partners with EPA. Rather, as the Supreme Court put it, Congress reacted to disaffection with pre-1970 state progress by 'taking a stick to the States in the form of the [1970 Act],' which 'sharply increased federal authority and responsibility in the continuing effort to combat air pollution.' ${ }^{6}$ For the first time, the states had to attain air quality of specified standards on a federally specified timetable. Notwithstanding Justice Kennedy's later characterization, congressional distrust of state performance also provided the rationale for jointly authorizing EPA and the states to enforce SIP provisions, and for providing a safety net in the form of citizen suit enforcement. ${ }^{65}$

60 President Richard M. Nixon, Special Message to the Congress on Environmental Quality (10 February 1970) (transcript accessed 28 June 2015 at www.presidency.ucsb.edu/ws/?pid=2757).

61116 Cong. Rec. 19,213 (remarks of Rep. Preyer).

62 Nixon, supra n.60.

63116 Cong. Rec. 19,206 (1970) (remarks of Rep. Springer).

64 Train v Natural Res. Def. Council, Inc., 421 US 60, 64-65 (1970). Cf. Union Elec. Co. v EPA, 427 US 246, 249, 256-57 (1976) (repeating the stick metaphor and noting that although the CAA gave states the primary responsibility to formulate control strategies, it subjected them to 'strict minimum compliance requirements' of a technology-forcing character).

65 See S. Rep. No. 91-1196, at 21 (1970). 
Congress cited several collective action rationales for increasing the federal role in air pollution control. First, it relied on race-to-the-bottom concerns to justify delegating to EPA the power to adopt nationally uniform emissions standards for new sources and hazardous air pollutants. According to a House report, both sets of standards would 'preclude efforts on the part of states to compete with each other in trying to attract new plants and facilities without assuring adequate control of extra-hazardous or large-scale emissions therefrom. ${ }^{66}$ Second, legislators cited superior federal expertise and resources (the resource pooling rationale for federal action) to support uniform federal standards.$^{67}$ Third, Congress decided to delegate to EPA exclusive power to adopt tailpipe emissions standards (with an exception for California) to address the need for uniformity. A Senate report accompanying earlier air pollution legislation stated that it would be more desirable to have national standards rather than for each State to have a variation in standards and requirements which could result in chaos insofar as manufacturers, dealers, and users are concerned.' ${ }^{68}$ Senator Muskie later explained that restricting state authority in this manner was appropriate because it was 'obviously in the public interest to reduce the variation in automotive emissions standards to an absolute minimum. ${ }^{69}$ Congress accommodated state interests primarily by authorizing the states to adopt controls (except for new motor vehicles) more stringent than EPA's. ${ }^{70}$

\section{The 1977 Amendments}

The 1977 amendments extended the deadlines for compliance with the NAAQS due to many states' failure to meet the original statutory timetable. They also added new programs, including permitting requirements for major stationary sources in both air quality control regions that had not yet met the NAAQS (nonattainment areas) and regions with air quality better than required by the NAAQS (PSD areas). Although some

66 H.R. Rep. No. 91-1146, at 2 (1970). See also S. Rep. No. 91-1196, at 49 (1970) (seeking to prevent states with adequate controls from being placed at a competitive disadvantage).

67 See e.g. 116 Cong. Rec. 19,206 (1970) (remarks of Rep. Springer).

68 S. Rep. No. 89-192, at 6 (1965).

69 Muskie, supra n.53, at 20. As indicated above, Congress allowed California to seek permission to enact more stringent standards because of its early efforts to control auto pollution and the severity of the state's pollution problems.

70 See S. Rep. No. 91-1196, at 15 (1970) (explaining the purpose of $\S 116$ of the 1970 Act). 
lawmakers expressed concerns about rising regulatory costs and increasing federal intrusion on state prerogatives, the dominant theme expounded throughout the legislative debate was the need for an even stronger federal role vis-à-vis the states. Legislators again invoked the specter of a race to the bottom, identifying as a key purpose of the amendments the prevention of industry's ability to foster competition for new business through the adoption of ever weaker state controls. ${ }^{71} \mathrm{~A}$ House report referred to this practice as "environmental blackmail.' ${ }^{2}$ The nonattainment provisions subjected states failing to meet NAAQS deadlines to new penalties and required them to submit SIP revisions. ${ }^{73}$ The amendments reduced state discretion to determine the appropriate mix of emissions controls needed to achieve the NAAQS by, among other things, requiring states with nonattainment areas to ensure that existing stationary sources in those areas implement reasonably available control measures for the nonattainment pollutants ${ }^{74}$ and to ensure that new or modified major stationary sources install emissions controls reflecting the lowest achievable emissions rate for those pollutants. ${ }^{75}$

Opponents of the new PSD provisions complained about unfair discrimination against the economic interests of states with clean air resources and protested the unwarranted federal intrusion on local governments' ability 'to protect clean air from people.' 76 The House committee report, however, actually lists the 'protection of States' rights' as a key justification for the PSD program. ${ }^{77}$ The Act delegated to the states 'primary responsibility' for administering the program, but required that they abide by minimum standards (measured as percentages of the NAAQS) regarded as 'essential to guarantee the individual States the right to decide to maintain air quality superior to minimum federal

71 H.R. Rep. No. 95-294, at 11, 133-35 (1977). See also Dwyer, supra n.56, at 1195 ('Because of their willingness to relax environmental standards to attract or keep economic development, states could not be trusted to adopt adequate standards.').

72 H.R. Rep. No. 95-294, at 195.

73 The amended sanction provisions are at 42 USC $\S 7509$.

7442 USC $\$ 7502(\mathrm{c})(1)$.

75 Ibid. at $\$ \$ 7502(\mathrm{c})(5), 7503(\mathrm{a})(2), 7501(3)$.

76 See e.g. 123 Cong. Rec. 18,135 (1977) (remarks of Sen. Garn). Some even charged that the PSD program amounted to a federal land use control system. See e.g. ibid. at 16,964 (remarks of Rep. Rousselot).

77 H.R. Rep. No. 95-294, at 105 (1977). Specifically, the PSD program was intended to protect states' rights to be free of interstate air pollution and to avoid the practice of 'environmental blackmail' described above. 
standards.' ${ }^{78}$ Indeed, a House report asserted that without the PSD provisions, the pre-existing guarantee that states would retain the power to adopt standards more stringent than EPA's would be meaningless. ${ }^{79}$ The same report also noted that the PSD program would help avoid the race to the bottom by precluding sources from 'shopping around' for locations with clean air and weak controls. ${ }^{80}$

Congress had authorized federal regulation of interstate pollution even before 1970 as a necessary response to transboundary externalities. ${ }^{81}$ The 1977 amendments sought to facilitate EPA efforts to enforce statutory restrictions on interstate pollution and authorized states to petition EPA for a finding that an upwind state was violating the statute by inadequately restricting emissions that prevented attainment or maintenance of the NAAQS in the petitioning state. ${ }^{82}$ The goal was to protect downwind states' interests by 'making a source at least as responsible for polluting another State as it would be for polluting its own State,' even if the source state's SIP did not prevent it from doing so. ${ }^{83}$

\section{The 1990 Amendments}

The 1977 amendments tilted the balance of federal-state authority significantly toward greater EPA control, protecting state autonomy mainly by reinforcing states' freedom to adopt controls more stringent than EPA's and by constraining the power of one state to prevent another from effectively controlling air pollution. The 1990 amendments took another step away from a regime even remotely resembling an 'equal partnership' between the two levels of government. The amendments were spurred by the persistent failure of some states to comply with the NAAQS and by the need to address newly discovered or inadequately addressed problems such as acid deposition and stratospheric ozone

78 Ibid. at 136. The Supreme Court described EPA's authority to issue orders halting construction of major facilities permitted by states notwithstanding regulatory deficiencies as 'notably capacious.' Alaska Dep't of Envtl. Conservation $v$ EPA, 540 US 461, 473-74 (2004). Another court later rejected the contention that EPA's implementation of the CAA's related visibility protection provisions 'trample[d] on discretion that Congress afforded states,' noting that the exercise of state responsibility is subject to federal oversight. Oklahoma $v$ EPA, 723 F.3d 1201, 1204 (10th Cir. 2013).

79 H.R. Rep. No. 95-294, at 136-37 (1977).

80 Ibid., at 133.

81 See Glicksman and Levy, supra n.46, at 594-95.

8242 USC $\$ 7426$.

83 S. Rep. No. 95-127, at 40 (1977). 
depletion. The amendments set new deadlines for NAAQS compliance in nonattainment areas, defined in much greater detail the steps necessary to move states with nonattainment areas toward compliance (and refined the sanctions available if states did not do so ${ }^{84}$ ), established a cap-and-trade program for coal-fired power plants that emitted acid rain precursors, stiffened interstate controls still further, ${ }^{85}$ phased out the manufacture and use of ozone-depleting chemicals to comply with US treaty commitments under the Montreal Protocol, and established a new permit program to help consolidate in one document all regulatory requirements applicable to a source.

Individual legislators predicted economic disruption. Senator Minority Leader Bob Dole called the bill 'the toughest environmental medicine America has ever had to take,' but supported it anyway. ${ }^{86}$ Other legislators protested the burdens the legislation would impose on some regions, such as those producing or whose sources burned large amounts of high-sulfur coal. ${ }^{87}$ Congress adopted the amendments in the face of this opposition. Senator Bentsen's response to those who opposed the acid rain provisions was that 'fairness' considerations had to be supplemented by state responsibility for the downwind harms caused by their sources, consistent with the 'polluter pays' principle. ${ }^{88}$ A House report noted that the amendments signaled that Congress was 'very serious' about air pollution control and 'will require all States to comply fully' with their CAA duties. States not making good faith efforts to comply would be severely sanctioned. ${ }^{89}$ The 'stick' Congress wielded in 1970 got larger in 1977 and larger still in 1990, notwithstanding preservation of the CAA's basic cooperative federalism architecture.

$84 \quad 42$ USC $\$ 7410(\mathrm{~m})$.

85 See e.g. GenOn REMA, LLC v EPA, 722 F.3d 513, 523 (3d Cir. 2013) ( Congress viewed the Federal government as continuing to play an essential role in the fight against interstate pollution despite the fact that the states are the primary actors for implementing NAAQS and formulating SIPs.').

86136 Cong. Rec. 36, 130 (1990).

87 See e.g. ibid., at 35,007 (remarks of Rep. Luken); ibid., at 35,016 (remarks of Rep. Applegate).

88 Ibid., at 36,129.

89 H.R. Rep. No. 101-490 (1990). 


\section{THE PERFORMANCE OF COOPERATIVE FEDERALISM UNDER THE CAA}

Congress's initial venture into environmental cooperative federalism is largely a success story. A 2013 minority report of the Senate Committee on Environment and Public Works, while highly critical of the Obama administration's implementation of the CAA, concluded that '[a]ir quality has significantly improved in the United States over the past 40 years, and the [CAA's] cooperative federalism arrangement deserves credit.' 90 Both emissions and ambient concentrations of the criteria pollutants covered by the NAAQS - the centerpiece of the statute and the primary focus of public health concern - have fallen significantly on a national basis, notwithstanding economic growth and population increases. ${ }^{91}$ Some programs administered by EPA without significant state assistance also have fared well. The acid deposition control's cap-and-trade program, for example, has reduced emissions of acid rain precursors generated by fossil fuel combustion at lower costs than anticipated. ${ }^{92}$ The statutory phaseout of ozone-depleting chemicals has helped shrink the hole in the ozone layer that increases risks for skin cancer and cataracts, although the hole is not expected to fully close before $2070 .{ }^{93}$ Retained state authority to adopt more stringent state controls has borne fruit in the form of ambitious state programs which have gone further than federal

90 Cooperative Federalism, supra n.14, at 11 . The criticism was directed at EPA's alleged treatment of states not as 'equal and valued partners,' but as objects of cooptation and coercion, and as 'mere regional offices of a massive federal environmental bureaucracy'. Ibid., at 13.

91 See Glicksman, Robert L. et al., Environmental Protection: Law and Policy, 7th edn (Wolters Kluwer, Austin, Boston, Chicago, New York, the Netherlands (2015), pp. 428-30. David Adelman, however, attributes most of the reduction in criteria pollutants to direct federal regulation, not the NAAQS program. See Adelman, David, 'Environmental Federalism: When Numbers Matter More than Size' (2014) 32 UCLA J. Envt'l L. \& Pol'y 238, 301-304.

92 See e.g. Glicksman et al., supra n.91, pp. 586-88; Goffman, Joseph, 'Title IV of the Clean Air Act: Lessons for Success of the Acid Rain Emissions Trading Program' (2006) 14 Penn. St. Envtl L. Rev. 177, 179-80.

93 See Culaba, Anne (January 2014) 'Good News: Ozone Hole Closing. Bad News: It Won't Recover Until 2070', RYOT News, accessed 30 June 2015 at www.ryot.org/full-recovery-ozone-layer-wont-happen-2070/499477. See also Driesen, David M. and Amy Sinden, 'The Missing Instrument: Dirty Input Limits' (2009) 33 Harv. Envtl L. Rev. 65, 85 ('Scholars recognize the phaseout of ozone-depleting chemicals as the major (some say the only) example of successful international environmental protection.'). 
controls (such as California's control of motor vehicle emissions) or preceded such controls (such as California's restrictions on GHG emissions). In some instances, one state's programs have spurred efforts by other states or EPA. ${ }^{94}$ Indeed, adoption of stringent state standards by a jurisdiction (like California) with a large market share for a regulated product such as new cars may induce manufacturers to conform their products globally to the standard to increase economies of scale, even in the absence of copycat regulation by other jurisdictions. ${ }^{95}$

The CAA is not an unalloyed cooperative federalism success story, however. Nonattainment persists, especially in major urban areas. Decades after Congress first mandated compliance with the NAAQS, more than 40 percent of US residents (more than 131 million people) live in counties with unhealthy levels of either ozone or particulate matter. ${ }^{96}$ Persistent nonattainment problems are due principally to emissions from mobile and small stationary sources (such as gas stations, paint emissions, and agricultural field burning), not from large industrial sources (with the exception of fossil fuel-fired electric power plants). ${ }^{97}$ Because the states are primarily responsible for regulating emissions from smaller sources under their SIPs (for example, through land-use plans and stationary source regulations), one might argue that nonattainment problems reflect inadequate federal oversight of NAAQS compliance

94 See e.g. Pawa, Matthew F., 'The Very Definition of Folly: Saving the Earth from Environmentalists' (2011) 38 BC Envtl Aff. L. Rev. 77, 80-81 (describing adoption by a dozen states of California's vehicle emission standards); Buzbee, William W., 'Preemption Hard Look Review, Regulatory Interaction, and the Quest for Stewardship and Intergenerational Equity' (2009) 77 Geo. Wash. L. Rev. 1521, 1551-52 (describing other states' desire to adopt California emissions standards for GHGs). See also Rocky Mountain Farmers Union v Corey, 740 F.3d 507, 511 (9th Cir. 2014) (Gould J, concurring in denial of rehearing en banc) (arguing that 'once states appreciate the benefits of [California's Low Carbon Fuel Standard], there may be a cascade of similar laws throughout the country - and perhaps federal action - aimed at stemming the tide of global warming').

95 See Stewart, Richard B., Michael Oppenheimer and Bryce Rudyk, 'Building a More Effective Global Climate Regime through a Bottom-Up Approach' (2013) 14 Theoretical Inquiries L. 273, 297-98.

96 American Lung Ass'n, Report on State of the Air 2013, at 8, accessed 30 June 2015 at www.lung.org/assets/documents/publications/state-of-the-air/stateof-the-air-report-2013.pdf; Adelman, supra n.91, at 301. For a complete list of nonattainment areas for all criteria pollutants, see 'Currently Designated Nonattainment Areas for All Criteria Pollutants', EPA, accessed 30 June 2015 at www.epa.gov/oaqps001/greenbk/ancl.html.

97 See Adelman, supra n.91, at § IV A-B. 
efforts. ${ }^{98}$ On the other hand, some characterize the new source review (NSR) program that requires permits for major stationary sources in nonattainment and PSD areas as unduly burdensome and needlessly intrusive on state prerogatives. ${ }^{99}$

Perhaps the most dysfunctional CAA provisions, however, are those restricting interstate air pollution. Before 1990, these restrictions accomplished little, as EPA and the courts consistently held that downwind states failed to prove that upwind sources significantly contributed to downwind state nonattainment. ${ }^{100}$ The 1990 amendments lessened the burden of proof for states soliciting EPA assistance in controlling upwind state sources contributing to downwind state nonattainment and allowed EPA to require upwind state regulation based on the aggregate contributions of groups of sources instead of having to trace problems to a single source. ${ }^{101}$ Judicial interpretation of the amended statute left EPA's efforts to mitigate interstate pollution in a shambles, however. The DC Circuit

98 EPA and the states actually share regulatory authority over motor vehicles: EPA establishes federal tailpipe emission standards, but states can also significantly reduce such emissions through transportation planning efforts and other regulatory mechanisms.

99 See e.g. Alaska Dep't of Envtl. Conservation v EPA, 540 US 461, 502-18 (2004) (Kennedy J dissenting); Gaines, Sanford E., 'Reflexive Law as a Legal Paradigm for Sustainable Development' (2003) 10 Buff Envtl LJ 1, 9 (raising possibility that NSR is impeding, not promoting emissions reductions); Murkowski, Senator Frank H., 'The Kyoto Protocol Is Not the Answer to Climate Change' (2000) 37 Harv. J. on Legis. 345, 361-62 (describing NSR as intrusive). Others have criticized NSR's grandfathering of existing sources, which arguably creates perverse incentives not to modernize old plants or competitive advantages for such plants. See e.g. Nash, Jonathan Remy and Richard L. Revesz, 'Grandfathering and Environmental Regulation: The Law and Economics of New Source Review' (2007) 101 Nw U.L. Rev. 1677, 1709-11; Revesz, Richard L. and Allison L. Westfahl Kong, 'Regulatory Change and Optimal Transition Relief (2011) 105 Nw U.L. Rev. 1581, 1628-32. Professor Adelman recommends scrapping NSR, thereby removing constraints on state regulatory choices in nonattainment and PSD areas. At the same time, he suggests giving EPA increased power to work with states and localities to address transportation control and small source emissions, which collectively are more responsible for nonattainment than large industrial sources. See Adelman, supra n.91, at $\S$ IV A-B.

100 See Glicksman, Robert L., 'Watching the River Flow: The Prospects for Improved Interstate Water Pollution Control' (1993) 43 J Urb \& Contemp L 119, 166-68; Crider, Kay M. 'Interstate Air Pollution: Over a Decade of Ineffective Regulation' (1988) 64 Chi-Kent L. Rev. 619.

101 See Glicksman, supra n.100, at 566-67. 
invalidated major regulatory initiatives by the Bush and Obama administrations. ${ }^{102}$ The Supreme Court reversed the DC Circuit's latest invalidation, upholding EPA's Cross-State Air Pollution Rule. ${ }^{103}$ The Court's decision did not resolve all issues concerning the Rule, however, and EPA's efforts to implement it are likely to face significant delays, including the possibility of additional litigation. ${ }^{104}$ The irony is that Congress authorized federal control of interstate air pollution in 1963, before authorizing any other federal air quality-related regulation. Fifty years later, the collective action problems arising from these transboundary externalities remain seemingly intractable.

\section{A COLLECTIVE ACTION-BASED RESPONSE TO CLIMATE CHANGE MITIGATION}

Climate change is the most significant problem facing environmental policymakers in the US and elsewhere. In the absence of a federal statute directed to controlling GHGs that contribute to climate change, EPA has addressed the problem under the CAA. ${ }^{105}$ Some contend that the CAA is ill suited to addressing climate change mitigation, a global problem with characteristics different from the localized air pollution problems targeted by the NAAQS program. ${ }^{106}$ Nevertheless, the CAA already addresses both regional (acid deposition) and global (stratospheric ozone depletion) transboundary problems, apparently quite effectively. The question is

102 EME Homer City Generation, L.P. v EPA, 696 F.3d 7 (DC Cir. 2012), rev'd \& remanded, 134 S Ct 1584 (2014); North Carolina v EPA, 531 F.3d 896 (DC Cir.), modified on reh'g, 550 F.3d 1176 (DC Cir. 2008).

103 EPA v EME Homer City Generation, L.P., 134 S Ct 1584 (2014).

104 See e.g. EME Homer City Generation, L.P. v. EPA, _ F.3d _ 795 F.3d 118 (DC Cir. 2015); Ambrosio, Patrick, "Attorney Says "Live Issues" Remain Following Supreme Court Decision on Cross-State Rule' (8 May 2014) 45 Env't Rep. (BNA) 1467; Childers, Andrew, 'Challenges Remain Despite Supreme Court Decision Reinstating EPA Cross-State Rule' (29 April 2014) BNA Env't Rep., accessed 30 June 2015 at www.bna.com/challenges-remain-despite-n17179890025/.

105 See Massachusetts $v$ EPA, 549 US 497 (2007) (holding that emissions of GHGs such as carbon dioxide are pollutants for CAA purposes, authorizing EPA to regulate them from mobile sources under $\S 202$ of the Act); Endangerment and Cause or Contribute Findings for Greenhouse Gases Under Section 202(a) of the Clean Air Act; CAA rulemakings, 74 Fed. Reg. 66,496 (15 December 2009).

106 Cf. Massachusetts v. EPA, 549 US at 559 (Scalia J. dissenting) (insisting that regulation of GHGs is not akin to regulating the concentration of some substance that is polluting the air'). 
whether the CAA's version of cooperative federalism, in which the federal government solicits state assistance but ultimately retains control, is a good fit for climate change mitigation.

Some environmental law experts, including Holly Doremus, have endorsed a cooperative federalism-based approach to climate change mitigation. ${ }^{107}$ Such an effort could entail direct federal technology-based regulation of mobile and new stationary source emissions, supplemented by state and local planning and implementation roles. As noted below, this is the approach that EPA has undertaken thus far, by establishing technology-based performance standards for motor vehicles and fossil fuel-fired power plants. Although there is not much state discretion in the implementation of the standards for motor vehicles and new power plants, EPA has issued a rule for existing power plants that allow states to experiment with a variety of implementation approaches - however, EPA retains final authority to review the adequacy of state implementation plans and issue a federal implementation plan if necessary.

A cooperative federalism approach to GHG regulation can be justified by collective action concerns. ${ }^{108}$ The presence of transboundary externalities, for example, justifies nationally (and internationally) led efforts to control GHGs. These externalities do not support preemption of more stringent state regulation, however, because such regulation will benefit all jurisdictions, not just the adopting state. As a result, California should retain its authority to adopt more stringent tailpipe emission standards and low carbon fuel standards. ${ }^{109}$

Retained state authority risks non-uniform regulation in the form of multiple state standards, but no more so than does the CAA's current

107 Doremus, Holly and W. Michael Haneman, 'Of Babies and Bathwater: Why the Clean Air Act's Cooperative Federalism Framework Is Useful for Addressing Global Warming' (2008) 50 Ariz. L. Rev. 799. Cf. Schapiro, Robert A., 'Not Old or Borrowed: The Truly New Blue Federalism' (2009) 3 Harv L \& Pol'y Rev. 34, 42 ('It is clear that the national government must be part of any solution. ... No one believes that global warming is best addressed by the states rather than the national government.').

108 See generally Glicksman and Levy, supra n.46, at 610-47.

109 For some examples of recent state policies to address GHG emissions, see Klass, Alexandra B. and Elizabeth Henley, 'Energy Policy, Extraterritoriality, and the Dormant Commerce Clause' (2013-2014) 5 San Diego J of Climate \& Energy L. 127. Such efforts may be vulnerable to challenges alleging unconstitutional extraterritorial application, however. See e.g. North Dakota v Heydinger, 15 F. Supp. 3d 891 (D Minn. 2014) (invalidating Minnesota's Next Generation Energy Act, which established energy and environmental standards relating to carbon dioxide emissions). 
preemption waiver. California has already demonstrated its leadership in controlling GHG emissions from mobile sources. ${ }^{110}$ Moreover, the uniformity rationale for exclusive federal regulation of new motor vehicle emissions does not apply to stationary source regulation, and does not justify preemption of more stringent state controls. Race-to-the-bottom concerns justify a federal floor on stationary source emissions to preclude states from competing for business by adopting weak GHG emission controls, but they do not justify preemption of more stringent state controls.

Superior resources suggest a significant federal role in developing climate change scientific information and at least a backup role in enforcement of mandatory state requirements. A closer question might be whether state regulation would undermine the international bargaining position of the US in extracting commitments from reluctant foreign nations, but at least two federal courts have rejected that rationale as a reason to preempt state GHG emission controls. ${ }^{11}$ Finally, the design of a climate change regime need not dwell on the NIMBY phenomenon because GHG emissions in one state generally have the same effects on climate change as emissions in any other place. Efforts to exclude a GHG-emitting source will therefore not benefit a state if its stringent regulations prompt a source to operate elsewhere. Indeed, the more salient problem may be the reverse in that a state that regards itself as at low risk from climate change (such as a landlocked state that need not fear sea level rise or coastal flooding) may be more inclined than a more vulnerable state to allow high levels of GHG emissions.

EPA has sought to achieve a balance between federal leadership and state autonomy in its regulation of GHGs under the CAA. In addition to developing federal performance standards for $\mathrm{CO}_{2}$ emissions from motor vehicles and some stationary sources, ${ }^{112}$ EPA issued technology-based emission

110 See Green Mountain Chrysler Plymouth Dodge Jeep v Crombie, 508 F Supp 2d 295, 394 (D Vt 2007).

111 Ibid.; Cent. Valley Chrysler-Jeep, Inc. v Goldstene, 529 F Supp 2d 1151 (ED Cal. 2007), reconsideration denied, 563 F Supp 2d 1158 (ED Cal. 2008).

112 Greenhouse Gas Emissions Standards and Fuel Efficiency Standards for Medium- and Heavy-Duty Engines and Vehicles 76 Fed. Reg. 57,106 (15 September 2011) (codified at 40 C.F.R. pts. 523, 534, 535, and 49 C.F.R. pts. 523, 534, 535); 2017 and Later Model Year Light-Duty Vehicle Greenhouse Gas Emissions and Corporate Average Fuel Economy Standards; Final Rule, 77 Fed. Reg. 62,624 (15 October 2012) (codified at 40 C.F.R. pts. 85, 86, 600, and 49 C.F.R. pts. 523, 531, 533, 536, 537); Standards of Performance for Greenhouse Gas Emissions from New, Modified, and Reconstructed Stationary Sources: Electric Utility Generating Units 80 Fed. Reg. 64,510 (23 October 2015) (to be codified at 40 C.F.R. pts. 60, 70, 71, 98), www2.epa.gov/sites/ 
guidelines in 2015 under $\S 111$ (d) for state regulation of $\mathrm{CO}_{2}$ emissions from existing electric generating units. ${ }^{113}$ The guidelines aim to reduce $\mathrm{CO}_{2}$ emissions from the power sector by approximately 32 percent from 2005 levels by 2030. To achieve this goal, EPA has created a "partnership between the EPA and the states' under which EPA will establish statespecific emission rate-based $\mathrm{CO}_{2}$ goals for the power sector and states will 'take the lead' on meeting those goals by creating plans that are consistent with EPA guidelines. ${ }^{114}$ According to EPA, the guidelines are 'based on, and reinforce, the actions already being taken by states and utilities' to upgrade existing electricity infrastructure. ${ }^{115}$ The regulatory approach also

provides flexibility for states to build upon their progress, and the progress of cities and towns, in addressing GHGs, and minimizes additional requirements for existing programs where possible. It also allows states to pursue policies to reduce carbon pollution that: (1) Continue to rely on a diverse set of energy resources; (2) ensure electric system reliability; (3) provide affordable electricity; (4) recognize investments that states and power companies are already making; and (5) tailor plans to meet their respective energy, environmental and economic needs and goals, and those of their local communities. ${ }^{116}$

Like the state implementation plan process that governs achievement of the NAAQS, ${ }^{117}$ EPA's $\S 111(\mathrm{~d})$ rule relies heavily on a cooperative federalism partnership: EPA establishes quantitative pollution reduction targets, states are afforded flexibility in deciding how they wish to achieve the federally specified targets, and states remain accountable

production/files/2015-08/documents/cpp-final-rule.pdf; Oil and Natural Gas Sector: Emission Standards for New and Modified Sources 80 Fed. Reg. 56,593 (18 September 2015) (to be codified at 40 C.F.R. pt. 60).

113 Carbon Pollution Emission Guidelines for Existing Stationary Sources: Electric Utility Generating Units 80 Fed. Reg. 64,662 (23 October 2015) (to be codified at 40 C.F.R. pt. 60, subpart UUUU), www.epa.gov/airquality/cpp/cps-final-rule.pdf).

114 Ibid. at 64,665. Although EPA will be responsible for setting the $\mathrm{CO}_{2}$ reduction goals, EPA has crafted these goals based on the unique position of each state, taking into account pre-existing state programs and policies such as state-wide regional cap-and-trade programs and renewable portfolio standards. See Section V ('The Best System of Emission Reduction and Associated Building Blocks') of the Final Rule for a detailed description of how EPA intends to establish state-specific $\mathrm{CO}_{2}$ emission reduction goals for the power sector. Ibid. at 64,663-811.

115 Ibid. at 64,678 .

116 Ibid. at 64,678-79.

117 Nevertheless, EPA has identified distinctions between the SIP and $\S 111(\mathrm{~d})$ processes. Carbon Pollution Emission Guidelines for Existing Stationary Sources: Electric Generating Units; Proposed Rule, 79 Fed. Reg. 34,830, 34,834 (18 June 2014). 
through EPA review of state plans and their implementation. The $\S 111$ (d) rule is noteworthy not only as an ambitious effort to use the CAA to reduce GHG emissions that contribute to climate change, but also as a program that recognizes and accommodates the need for states to craft policies and programs suited to their own needs and the capacities of affected stakeholders. Notwithstanding this accommodation, and consistent with the cooperative federalism model threaded throughout the CAA, the federal government retains the final say over pollution reduction goals and the capacity to step in if states fail to abide by their responsibilities. ${ }^{118}$

\section{CONCLUSION}

The CAA initiated cooperative federalism in US environmental law. Its design should be well understood, along with the strengths and weaknesses of its federalism model in combatting air pollution. Fundamental misconceptions nevertheless persist about why Congress relied on both federal and state governments to control air pollution. Despite judicial characterizations that the CAA created an equal partnership between EPA and the states, it was never intended to do so. EPA has always been in charge, notwithstanding delegation of discretion to the states to determine how best to fashion an emission control strategy capable of achieving the NAAQS set by EPA to meet federally determined air quality goals. Even in that realm, EPA's authority increased and state prerogatives narrowed as states failed to satisfy NAAQS deadlines. The statute was not principally an effort to protect states' rights, notwithstanding traditional state police power authority to address public health risks. Congress repeatedly chose to protect state authority to regulate more rigorously than the federal government, not the authority to reach divergent judgments about the appropriate balance between promoting economic activity and protecting human health.

An accurate understanding of the nature of cooperative federalism under the CAA is critical. It is difficult for policymakers to fix problems and for judges to review implementation of the statute if they do not appreciate how the statute was meant to work. Similarly, efforts to adapt the CAA to meet climate change challenges by increasing or decreasing the federal or state role for particular tasks are more likely to succeed if they are based on a proper understanding of the existing statutory foundation.

118 See Federal Plan Requirements for Greenhouse Gas Emissions from Electric Utility Generating Units Constructed on or Before January 8, 2014; Model Trading Rules; Amendments to Framework Regulations; Proposed Rule, 80 Fed. Reg. 64,966 (23 October 2015). 